\title{
Recovery of pure economic loss in China: Current situation, problems and future prospects
}

Citation for published version (APA):

Yan, Y., \& Faure, M. G. (2020). Recovery of pure economic loss in China: Current situation, problems and future prospects. Journal of European Tort Law, 11(3), 286-313. https://doi.org/10.1515/jetl-2020-0144

Document status and date:

Published: 01/01/2020

DOI:

10.1515/jetl-2020-0144

Document Version:

Publisher's PDF, also known as Version of record

Document license:

Taverne

Please check the document version of this publication:

- A submitted manuscript is the version of the article upon submission and before peer-review. There can be important differences between the submitted version and the official published version of record.

People interested in the research are advised to contact the author for the final version of the publication, or visit the DOI to the publisher's website.

- The final author version and the galley proof are versions of the publication after peer review.

- The final published version features the final layout of the paper including the volume, issue and page numbers.

Link to publication

\footnotetext{
General rights rights.

- You may freely distribute the URL identifying the publication in the public portal. please follow below link for the End User Agreement:

www.umlib.nl/taverne-license

Take down policy

If you believe that this document breaches copyright please contact us at:

repository@maastrichtuniversity.nl

providing details and we will investigate your claim.
}

Copyright and moral rights for the publications made accessible in the public portal are retained by the authors and/or other copyright owners and it is a condition of accessing publications that users recognise and abide by the legal requirements associated with these

- Users may download and print one copy of any publication from the public portal for the purpose of private study or research.

- You may not further distribute the material or use it for any profit-making activity or commercial gain

If the publication is distributed under the terms of Article $25 \mathrm{fa}$ of the Dutch Copyright Act, indicated by the "Taverne" license above, 


\title{
Yu Yan* and Michael Faure \\ Recovery of Pure Economic Loss in China: Current Situation, Problems and Future Prospects
}

https://doi.org/10.1515/jetl-2020-0144

\begin{abstract}
Should pure economic loss be compensated in China? If so, to what extent? Both questions are left unsolved in the established literature. We contribute to the existing literature by showing that the Chinese courts have developed a relatively conservative attitude towards the compensation of pure economic loss and that the arguments adopted by the courts to deny recovery are neither fair nor reasonable. Using the law and economics analysis, we have recourse to four complementary solutions. First, pure economic loss cases involving socially relevant losses should be compensated. Second, when social losses are not involved, pure economic loss should also be compensated if the third parties are willing to pay or have paid for protection against such a loss. Third, to relieve the excessive pressure imposed by the compensation for such loss, the concepts of causation and the duty of the victim to mitigate damage need to be further clarified in Chinese laws. Fourth, when determining the amount of compensation for pure economic loss, we should carefully balance the trade-off among a variety of factors, including the extent to which the damage could have been foreseen, the nature of the loss, the blameworthiness of the tortfeasor, the size of the plaintiff class, the public policy toward professional standards, the victim's private loss, the social loss, the courts' capacities to calculate the loss, and the third parties' willingness to pay for protection against the loss.
\end{abstract}

Keywords: pure economic loss, tort, compensation, China, law and economics analysis

Note: Yu Yan acknowledges financial support from the Postdoctoral Research Foundation of China (2020M671931) and the Fundamental Research Funds for the Central Universities (CN) (20720191065).

*Corresponding author: Yu Yan, Assistant Professor of Law, School of Law, Xiamen University, China, E-Mail: yanyu@xmu.edu.cn

Michael Faure, Professor of Comparative and International Environmental Law, Maastricht University and Professor of Comparative Private Law and Economics, Erasmus School of Law Rotterdam, both the Netherlands, E-Mail: michael.faure@maastrichtuniversity.nl 


\section{Introduction}

Pure economic loss refers to a financial loss that a person suffers, without accompanying harm to their health or property. ${ }^{1}$ In this respect, pure economic loss is different from consequential economic loss, which is usually connected with (even the slightest) damage to the victim or their property. ${ }^{2}$ Consequential economic loss is normally recoverable because it presupposes the existence of physical injuries. By contrast, pure economic loss only strikes the victim's wallet and nothing else. Therefore, it is still open for debate whether, and if so to what extent, the recovery of pure economic loss should be allowed.

Given the nature of pure economic loss, there is substantial variance across different legal systems regarding the extent to which pure economic loss in tort can be recovered. For instance, in Europe, a distinction can usually be made among liberal regimes (ie Belgium, France, Greece, Italy and Spain), conservative regimes (ie Austria, Finland, Germany, Portugal and Sweden), and pragmatic regimes (ie England, Scotland, and the Netherlands). ${ }^{3}$ The liberal regimes often deal with pure economic loss autonomously in tort and they are characterised by the principle absence of any objection to compensate pure economic loss. ${ }^{4}$ On the contrary, in the conservative regimes, pure economic loss does not belong to the 'absolute rights' which receive protection under tort law. ${ }^{5}$ If a remedy is available, it will either be based on a specific tort provision or on an expansive application of contract principles. ${ }^{6}$ Therefore, the liberal regimes start from an inclusive position that allows the recovery of pure economic loss in principle, whereas the conservative regimes start from an exclusive position that denies the recovery

1 This definition is given by C van Dam, European Tort Law (2nd edn 2013) 208.

2 The difference between pure economic loss and consequential economic loss is discussed by many scholars. See among many others WH van Boom, Pure Economic Loss: A Comparative Perspective, in: WH van Boom/H Koziol/C Witting (eds), Pure Economic Loss (2004) 1; and M Bussani/ VV Palmer, The notion of pure economic loss and its setting, in: M Bussani/VV Palmer (eds), Pure Economic Loss in Europe (2003) 3.

3 The division is made by Bussani and Palmer. See M Bussani/VV Palmer, The liability regimes of Europe - their façades and interiors, in: M Bussani/VV Palmer (eds), Pure Economic Loss in Europe (2003) 120. These authors also realised that the division is a highly condensed summary reflecting the individual national legislative style, but it is incomprehensible, as each country's liability regime and legal culture are ignored.

4 Ibid, $123 f$.

5 Ibid, 124.

6 Ibid, 125. 
in the first place. ${ }^{7}$ For the practical regimes, unlike the liberal and conservative regimes, the recovery of pure economic loss is neither driven by a wide tort principle nor by a checklist of absolute rights. ${ }^{8}$ Instead, the pragmatic regimes are characterised by a cautious case-by-case approach, which carefully considers the actual socio-economic implications of allowing compensation for pure economic loss (principally via 'the duty of care' concept). ${ }^{9}$

When it comes to China, the concept of pure economic loss was not sufficiently recognised, neither among policymakers nor by academics before the 2000s. Although there is no solid evidence to support this fact, we do observe that, in practice, the recovery of pure economic loss was rarely approved by tort law before the 2000s. ${ }^{10}$ From the start of the 21st century, there has been an increasing number of cases in China which involved the recovery of pure economic loss. ${ }^{11}$ Also, since that time, the issue of the recovery of pure economic loss has

7 See M Bussani/VV Palmer, General conclusions of the study, in: M Bussani/VV Palmer (eds), Pure Economic Loss in Europe (2003) 531.

8 See Bussani/Palmer (fn 3) 124.

9 For example, in the United Kingdom and Hong Kong, judges normally use three different but overlapping tests (the 'Caparo' test, the 'Hedley Byrne' test, and the 'incremental' approach) to decide whether to impose a duty of care on the defendant in claims that involve pure economic loss. To establish the duty of care under the 'Caparo' test, harm must be foreseeable, the plaintiff and the defendant must be in a relationship of proximity, and it must be fair, just, and reasonable to impose liability - see Caparo Industries plc v Dickman [1990] 2 Appeal Cases (AC) 605. To establish the duty of care under the 'Hedley Byrne' test, the tortfeasor should have assumed responsibility towards the victim, and the victim has to rely reasonably on that assumption of responsibility (see Hedley Byrne \& Co Ltd v Heller \& Partners Ltd [1964] AC 465). Last, the so-called 'incremental' approach, which is derived from the Caparo case, directs the courts to develop novel categories of negligence analogically with the established one. For a critical review of all these tests and suggestions for reform, see PJ Yap, Pure Economic Loss and Defects in the Law of Negligence (2009) 17 Tort L Rev 99, 80-99; and $K$ Barker, Wielding Occam's Razor: Pruning Strategies for Economic Loss (2006) 26 Oxford Journal of Legal Studies (OJLS) 289, 289-302.

10 When searching the keyword 'pure economic loss' in ChinaLawInfo (the largest online database on Chinese cases), we could find 168 cases related to this issue, all of which were dealt with by courts after 2000. The search results via the ChinaLawInfo also show that, before 2006, only two pure economic loss cases were closed by courts (one in 2005 and one in 2006). However, after 2006, the number of pure economic loss cases had increased to 166 by the date of our last access (on 16 December 2020).

11 For example, one study pointed out that, in the 1990s, the issue of 'pure economic loss' did not attract much attention, either from the legislator or from academic scholars. See YS Ge, Chuncui Jingji Sunshi de Peichang Yu Yiban Qinquan Xingwei Tiaokuan [The Recoverability of Pure Economic Loss and the General Provisions of Tort], 21 Peking University Law Journal (Peking Univ LJ) (2009) 689, $710 \mathrm{f}$. 
gradually drawn the attention of Chinese legal scholars. Nowadays, it is commonly accepted that art 106 of the 1987 General Principles of Civil Law (GPCL) ${ }^{12}$ and art 2 of the 2010 Tort Liability Law (TLL) ${ }^{13}$ can be interpreted as the general bases for protecting pure economic loss in China. ${ }^{14}$ According to art 106 of the GPCL,

...where a citizen or legal person through fault interferes with and causes damage to state or collective property, or to the property or person of another, he/she must bear civil liability.

Art 2 of the TLL further explains,

...civil rights and interests... include the right to life, the right to health, the right to name, the right to reputation, the right to honour, right to self-image, right of privacy, marital autonomy, guardianship, ownership, usufruct, security interest, copyright, patent right, exclusive right to use a trademark, right to discovery, equities, right of succession, and other personal and property rights and interests.

Taking these two articles together, it seems that Chinese tort law protects not only breaches of the so-called 'absolute rights', but also breaches of 'other personal and property rights and interests. ${ }^{15}$ In other words, these articles seem to have a broad coverage, and do not appear to exclude the recovery of pure economic loss. Therefore, if one only considers these articles, China might be classified as one of the liberal regimes. However, in practice, Chinese courts still take a conservative

12 The GPCL is considered as the basic law (jiben falü) on civil matters. More information of the GPCL and its significance can be found at LH Zhang, Latest Developments in the Codification of Chinese Civil Law (2008) 83 Tulane L Rev 999, 999-1039. This Law came into effect in 1987 and is still valid. An English translation of the GPCL is also provided by W Gray/HR Zheng, General Principles of Civil Law of the People's Republic of China (1986) 34 The American Journal of Comparative Law (AJCL) 715, 715-743. However, it should be noted that the Chinese legislator did not take the protection of pure economic loss into account when drafting art 106 of the GPCL. See XB Zhang/ $X Y$ Zhang, Lunchuncui Jingji Sunshi de Jige Jiben Wenti [On Several Basic Problems about Pure Economic Loss] (2007) 7 Law Science Magazine 15, 18.

13 The TLL is promulgated by the Standing Committee of the NPC and came into effect on 1 July 2010.

14 This argument is made by $L M$ Wang, Qinquanfa Yiban Tiaokuan de Baohu Fanwei [The Scope of Protection by General Provision in Tort Law] (2009) 3 The Jurist 19. See also Ge, 21 Peking Univ LJ (2009) 689, 699-711; and XB Zhang, Legislation of Tort Liability Law in China (2018) 159-178. Note that, the GPCL and the TLL will be abrogated as of 1 January 2021. Nevertheless, both art 106 of the GPCL and art 2 of the TLL are adopted by arts 1165 and 990 of the new Civil Code in China respectively. The contents of these articles remains almost unchanged.

15 See Zhang (fn 14) 159-178. 
approach and recovery of pure economic loss is largely restricted. ${ }^{16}$ In fact, over the last two decades, legal scholars, courts, and legislators in China have been facing increasing challenges related to the recoverability of pure economic loss. ${ }^{17}$ The following questions continuously arise, for example, about the extent to which, and in what ways, pure economic interests should be protected in China. Are there any effective frameworks for dealing with pure economic loss? Before answering these questions, it is necessary to take a closer look at the current situation in China with respect to the recoverability of pure economic loss. It is also necessary to investigate the challenges faced by Chinese courts in practice. Only then can we propose some guidelines for the future that might be helpful to Chinese legislators.

This paper is structured as follows. Section II reviews the various approaches taken by Chinese courts when dealing with the recovery of different pure economic loss cases. Section III briefly summarises the results of the case studies. Sectio$\mathrm{n}$ IV critically evaluates the arguments for the exclusion of pure economic loss provided by Chinese courts. Section V concludes and provides several policy recommendations.

\section{Typical pure economic loss cases in China}

The legal basis for recovering pure economic loss in China seems to be very general, causing difficulties in attaining a complete understanding of the recoverability of pure economic loss in practice. To remedy this, we should, in particular, pay attention to pure economic loss cases in addition to the doctrinal rules. Certain elements in those cases, such as general propositions, definitions, reasons and holdings, should also be discussed.

In this section, we analyse several pure economic loss cases in China. These cases are fairly typical, because most of them are guiding cases (zhidao anli) that are chosen by the Supreme People's Court (SPC). ${ }^{18}$ They are of great importance,

16 This restrictive approach is also observed by many Chinese scholars. See among many others Zhang (fn 14) 143; and Ge, 21 Peking Univ LJ (2009) 689, 699-711.

17 More discussion on the problems faced by Chinese courts and scholars in practice can be found in Zhang (fn 14) 459-473 and Ge, 21 Peking Univ LJ (2009) 689, 699-711.

18 To make the judgments more consistent, the SPC launched the Guiding Case System (GCS) in 2010. Now, the GCS is regulated by the 2010 Provisions Concerning SPC's Work on Case Guidance. Under the GCS, each year the SPC will select and publish several representative cases as the Guiding Cases. Such a system was further specified in the 2015 Detailed Rules of Implementation of the Provisions of the Supreme People's Court on Case Guidance Work. More information on the GCS, as well as its scope of authority and its adoption and importance in practice, is provided by J Mark, 
as lower courts should 'refer to' (canzhao) these guiding cases when handling cases with similar facts. As a result, these selected cases may provide a 'snapshot' of the recoverability of pure economic loss in China.

Generally speaking, pure economic loss cases in China can be classified into five categories: 1) the unfair competition case; 2 ) the flawed provision of professional services or advice case; 3 ) the interference with business case; 4) the cable case, and 5) the transferred loss case. ${ }^{19}$ The following subsections will discuss these cases respectively.

\section{A Case One: unfair competition}

In Ju County Winery $v$ Wendeng Brewery Factory, ${ }^{20}$ the defendant used the trademark 'qifengjiu' (identical to that of the plaintiff) on its wine, causing sales of the plaintiff to decrease. The defendant was judged to have violated the plaintiff's exclusive right to trademark by the court of first instance. Based on these grounds, the court deemed that the defendant should be liable to pay compensation for the plaintiff's loss of profits. However, the court of appeal disagreed with the reasoning given by the court of first instance. According to the court of appeal, the defendant's act was misleading rather than infringing the plaintiff's exclusive right to trademark. It then stated that arts 4, 5 and 7 of the GPCL should be the

Chinese Common Law? Guiding Cases and Judicial Reform (2016) 129 Harvard L Rev 2213, 22132234; and M Zhang, Pushing the Envelope: Application of Guiding Cases in Chinese Courts and Development of Case Law in China (2017) 26 Washington International Law Journal 269, 269-306. Background information on the conditions under which the GCS emerged and evolved is provided by SC Wang, Guiding Cases as a Form of Statutory Interpretation: Expansion of Supreme People's Court's Judicial Lawmaking Authority in China (2019) 48 Hong Kong Law Journal (HKLJ) 1067, 1067-1096.

19 Even though our classification does not include all cases that involve pure economic loss, our interest lies in tracing the most recurrent patterns, which we refer to as the 'typical cases'. Note that a different classification is given in the existing literature. For example, Bussani \& Palmer hold that the typical instances of pure economic loss include four different cases: the 'ricochet loss' case, the 'transferred loss' case, the 'closure of public markets, transportation corridors and public infrastructures' case, and the 'reliance upon flawed data, advice or professional services' case. See Bussani/Palmer (fn 3) 10-13. Van Boom (fn 2) 6f by contrast, focuses on the parties involved in the cases and divides the cases into two groups: the 'two party pure economic loss' case and the 'three party economic loss' case.

20 See Ju County Winery $v$ Wendeng Brewery Factory (Juxian jiuchang $v$ Wendeng niangjiuchang buzhengdang jingzheng jiufen'an) (2 January 1990) Shandong SPC (Court of Second Instance). 
correct legal bases for the defendant to pay compensation. ${ }^{21}$ These articles read as follows:

Art 4: 'In civil activities, the principles of offering of one's own free will, fairness, making compensation for equal value, honesty and credibility shall be observed.'

Art 5: 'The lawful civil rights and interests of citizens and legal persons shall be protected by law; no organisation or individual may infringe upon them.'

Art 7: 'Civil activities shall have respect for social ethics and shall not harm the public interest, undermine State economic plans or disrupt the social economic order.'

Judges from the court of appeal considered that the defendant had not acted with honesty and credibility, had disrupted the social economic order, and infringed the 'lawful interests' of the plaintiff. Thus, the defendant should be liable to pay for the loss of profits sustained by the plaintiff. Moreover, judges from the court of appeal also realised that, even though the anti-unfair competition law had not been promulgated at the time when this case occurred, this case was essentially a case of unfair competition. In 1993, the 1993 Law Against Unfair Competition was enacted. Now, arts 6 and 17 of this Law clearly state that a business operator might be entitled to claim compensation of pure economic loss (ie the loss of profits) from his/her competitor if the competitor interfered with his/her business through unfair competition. ${ }^{22}$

\section{B Case Two: flawed professional advice and services}

Cases of flawed professional advice and services concern the liability of those who provide professional advice, prepare data or render services. Intentionally or carelessly drafted advice or statements could cause damage to the contractual counterparty. For example, in Chen Lihua et al v Daqing Lianyi Company \& Shenyin

21 The court of first instance used art 3 of the 1983 Trademark Law and art 118 of the GPCL as the main legal bases for granting compensation to the plaintiff. The former article states, '... the trademark registrants shall enjoy the exclusive right to use the trademarks, and be protected by law.' The latter article states, 'if... the rights to exclusive use of trademarks are infringed upon by such means as plagiarism, alteration or imitation, they shall have the right to demand that the infringement be stopped, its ill effects be eliminated and the damages be compensated for.'

22 The 1993 Law Against Unfair Competition was not promulgated by the Standing Committee of the NPC until 2 September 1993. This law was then amended on 4 November 2017. 
Securities Company, ${ }^{23}$ the defendant made a false statement by overstating its net profits, which was not discovered by a securities underwriter. As a result, Chen Linhua and the other twenty-two persons who invested in the defendant's stock suffered significant losses. The court of first instance held that the defendant should be liable to pay for the investors' losses, on the basis of art 21 of the 1993 Interim Provisions on the Management of the Issuing and Trading of Stocks ${ }^{24}$ and art 27 of the 2003 Some Provisions of the SPC on Trying Cases of Civil Compensation Arising from False Statements in the Securities Market. ${ }^{25}$ According to the court, the defendant knowingly and deliberately made the false statement and the investors' losses were causally related to this false statement. The defendant appealed to a higher court, arguing that the investors' losses were not caused by its false statement but by the systemic risks of the stock market. However, the higher court rejected the appeal, because the defendant did not provide sufficient evidence to prove the causal link between the systemic risks in the stock market and the investors' losses.

Liability for conduct induced by the over-valuation of a company also arises in other cases. For instance, in one case, the plaintiff relied on an audit report that carelessly over-stated the net financial value of the defendant and signed a sales agreement with the defendant whose financial situation was actually very poor. ${ }^{26}$ As a result, the defendant was not in a position to perform their contractual duties and responsibilities, causing losses to the plaintiff. Moreover, in this case, a bank was found to have negligently issued a false proof of deposit to a travel agency. Based on this proof of deposit, an accounting firm carelessly issued the erroneous audit report. Because of all these facts, the court decided that the travel agency as

23 See Chenlihua dengershisan ming touziren v Daqing lianyi gongsi \& Shenyin zhengquan gongsi xujia chenshu qinquan peichang jiufen'an (Chen Lihua et al $v$ Daqing Lianyi Company \& Shenyin Securities Company) (21 December 2004) Helong Jiang SPC (Court of Second Instance).

24 Art 21 states, '... in contracting for underwriting, the securities management organisations should verify the truthfulness, accuracy and completeness of the prospectus and other related publicity materials. If the documents are found to contain false and seriously misleading statements or major omissions, they should not issue an invitation or offers. If the offers have been issued, the selling activities must be stopped immediately and at the same time remedial measures shall be taken.'

25 Art 27 states, '.. . where a securities underwriter, a person recommending the listing of securities or a professional intermediation service organisation who knows or ought to know the issuer's or listed company's false statement, but does not correct it or issue reserved opinions, his behaviour shall constitute a joint tort, and he shall bear joint liability for the losses caused to the investors.'

26 See Nanfang Hangkong Lüyou Gongsi v Yulong Lüxingshe deng Daixiao Hetong Jiufen'an (China Southern Airlines Travel \& Tourists Company v Yulong Travel Agency et al) (20 November 1998) Interim People's Court of Haikou (Court of Second Instance). 
well as the bank and the accountant were jointly and severally liable to compensate the plaintiff's damage. This decision was mainly based on the provisions of art 106 of the GPCL and two judicial replies that were issued by the SPC. ${ }^{27}$

Moreover, defectively rendered advice and services could also cause damage to others besides the direct contractual counterparty. For example, in Wang Baofu $v$ Beijing Sanxin Law Firm, ${ }^{28}$ Wang Shouzhi wanted his son, Wang Baofu (the plaintiff), to inherit his estate. Wang Shouzhi prepared a will by himself and signed a contract with Sanxin Law Firm. According to the contract, the law firm should serve as a witness to Wang Shouzhi's will. However, Wang Shouzhi's will was frustrated by a number of errors. For example, Wang Shouzhi forgot to write down the date and the law firm only assigned one attorney to perform the task. ${ }^{29}$ As a result, Wang Shouzhi's son (the plaintiff) could only inherit a part of the estate instead of the entire estate that his father had intended to leave him. The plaintiff thus sued the law firm to claim compensation for the damage incurred.

The court of first instance decided that the law firm should be liable for the plaintiff's damage on the basis of the provisions of art 106 of the GPCL, according to which, anyone who can prove that an attorney was at fault in causing damage should be entitled to recover their losses. Moreover, the court further held that the aim of the contract between the plaintiff's father and the law firm was to 'guarantee the validity of the will (through the attorney's expert knowledge), so that the plaintiff could inherit the whole estate successfully.' However, in this case, the law firm did not perform this professional duty appropriately, resulting in damage to the plaintiff. Thus, the law firm should be liable for the damage it negligently caused.

27 See 1997 Reply of the SPC on How to Divide the Loss Suffered by Multiple Creditors Among Verification Organisations, which was issued by the SPC on 31 December 1997. See also the 1998 Reply of the SPC on the Liability of Accounting Firms If They Issued a False Capital Verification Certificate to Enterprises, which was issued by the SPC on 26 June 1998. Another legal basis for the recovery of pure economic loss caused by a flawed accounting service is provided by art 42 of the 1993 Law on Certificated Public Accountants, which was issued by the Standing Committee of the NPC on 31 October 1993. This article states that, 'if a public accounting firm has in violation of the provisions of this Law caused losses to its client or other interested parties, it shall bear the liability for compensation according to law.' However, since this article seems to be very general, it was not used by the court in China Southern Airlines Travel \& Tourists Company v Yulong Travel Agency et al (fn 26).

28 See Wangbaofu v Sanxin lüshi shiwusuo caichan sunhai peichang j̈ufen'an (Wang Baofu v Beijing Sanxin Law Firm) (1 December 2004) Beijing No 2 Interim People's Court (Trial of Second Instance). 29 Art 17 of the 1985 Law of Succession in China requires, '... a will written on behalf of the testator shall be witnessed by two or more witnesses, of whom one writes the will, dates it and signs it along with the other witness or witnesses and with the testator...' 
The law firm filed an appeal to a higher court, arguing that they should not be liable to compensate the plaintiff's loss. The appeal was not supported by the higher court. However, the explanations that the higher court gave were slightly different from those given by the court of first instance. More specifically, the higher court's decision was mainly based on the first paragraph of art 49 of the 1996 Lawyers Law, ${ }^{30}$ rather than art 106 of the GPCL. According to the former article,

...where a lawyer engages in legal practice in violation of law or causes losses to a party due to his fault, the law firm where the lawyer works shall bear the liability for compensation. After paying compensation, the law firm may claim recovery from the lawyer who acted intentionally or out of gross negligence.

In the meantime, the higher court has stated that it was not wrong for the court of first instance to apply art 106 of the GPCL. Apparently, this case of poor legal services shows that third parties may suffer pure economic loss when they rely on services or advice that are carelessly provided by experts.

\section{Case Three: interference with business}

In Shanghai Lanqi Telecommunication Equipment Co, Ltd v Shanghai Yangpu Digital Market Management Co, Ltd, the plaintiff rented a shop (which is owned by the defendant) to sell mobile phones. ${ }^{31}$ On 25 May 2005, the plaintiff signed a sales contract with a third party, Shanghai Baina Office Equipment Co, Ltd. Under this contract, the plaintiff was required to deliver 2,000 mobile phones (worth CNY 1.6 million, EUR 240,000) on 29 May. Moreover, if these mobile phones could not be delivered on time, the plaintiff would be charged $15 \%$ of the contract value on the basis of the liquidated damages clause in the contract. However, on 29 May, the defendant prevented the plaintiff from moving the mobile phones out of the shop, because the plaintiff had not paid the rent on time. As a result of the defendant's act, the plaintiff was unable to send these mobile phones to its customer on time and was required to pay liquidated damages to its customer.

30 The 1996 Lawyer's Law in China was enacted by the Standing Committee of the NPC. It was amended three times afterwards, in 2007, 2012, and 2017.

31 See Shanghai lanqi dianxun shebei youxian gongsi v Shanghai yangpu saibo shuma shichang jingying guanli youxian gongsi qinhan qiye jingyingquan jiufen'an (Shanghai Lanqi Telecommunication Equipment Co, Ltd v Shanghai Yangpu Digital Market Management Co, Ltd) (23 December 2005) No 2 Interim People's Court of Shanghai (Court of Second Instance). 
The plaintiff sued the defendant, claiming compensation for its payment of liquidated damages. The court of first instance rejected the plaintiff's claim, based on the reason that the plaintiff did not have sufficient evidence to prove that the defendant intended to cause its loss. However, a higher court approved the plaintiff's claim, on the basis of arts 5 and 106 of the GPCL. According to the higher court, the debated issues are whether the defendant had intended to cause the plaintiff's damage and whether the plaintiff's losses were causally linked to the defendant's act. In this case, the court first stated that the plaintiff's right to operate a business is protected by law. It then held that the defendant could have foreseen the plaintiff's urgent need to deliver phones on time and thus have foreseen the plaintiff's loss, because the plaintiff had previously contacted the defendant on many occasions and had even called the police to prevent the defendant's act. Based on these facts, the court concluded that the defendant should be liable to compensate the plaintiff's loss, since the former intended to cause the loss and a causal link existed between his act and the plaintiff's loss. ${ }^{32}$ It seems that the court used two criteria to examine the defendant's intent: first, whether the defendant infringed a legally protected right or interest with intent; second, whether the defendant could have foreseen the particular damage.

By contrast, if the defendant negligently rather than intentionally infringes the plaintiff's right to operate a business, they may not be liable to compensate the pure economic damage suffered by the plaintiff. One illustrative example is Yongkang Liangda Electronics Factory $v$ Yongang Ruiying Industry and Trade et al. ${ }^{33}$ In this case, the plaintiff's claim for the loss of production was also rejected by the court, based on arts 106 and 117 of the GPCL. The reason given by the court was that the plaintiff's loss was actually a loss of expected profit, which is uncertain in nature. The plaintiff did not present sufficient evidence to prove that such a loss could be anticipated.

32 In another case, Liu Junfa $v$ Liu Liumei deng qinquan zeren jiufen (Liu Junfa $v$ Liu Liumei et al) (23 May 2017) Shaoguang Interim People's Court (Court of Second Instance), the defendant intentionally blocked the entrance to the plaintiff's pig farm, causing the plaintiff to lose a considerable amount of profits. The plaintiff's claim for the loss of profits was also supported by the court.

33 See Yongkangshi liangda wujin dianqichang geren duzi qiye $v$ Yongkangshi ruiying gongmao youxian gongsi deng caichan sunhai peichang jiufen'an (Yongkang Liangda Electronics Factory $v$ Yongang Ruiying Industry and Trade et al) (26 September 2016) Jinkang Interim People's Court (Court of Second Instance). In this case, a cable in the defendant's shop caught fire. The fire rapidly spread to the plaintiff's premises, causing loss of some property and production. 


\section{Case Four: cable cases}

In Chongqing Minzu Hospital v Chongqing Yong'an Construction Co, Ltd et al, employees of Yong'an Construction Company negligently cut through a cable belonging to a State-owned power company that supplied electricity to Minzu Hospital. ${ }^{34}$ The unexpected power cut lasted twenty-six hours. At trial, the plaintiff argued that normally the daily operating revenue of the hospital was approximately CNY 60,000 (EUR 9,000) on average. However, during the power cut, the daily operating revenue declined to CNY 13,246 (EUR 1,987). At trial, the plaintiff's claim for compensation of lost profits was approved by the court of first instance, but the amount of compensation was reduced to CNY 25,000 (EUR 3,750). The legal basis here was art 60 of the 1996 Electric Power Law, ${ }^{35}$ which states, 'electric power enterprises that cause consumers or a third party damage with fault (guocuo) shall bear liability for compensation according to law. ${ }^{36}$

However, the court of second instance quashed the judgment reached by the court of first instance. The reasons that they gave deserve our attention. First, they made it clear that 'pure economic loss refers to the financial loss suffered by a person, with no damage to person or property.' The court then stated that 'such loss should generally not be recovered; one exception is that such loss was caused by the defendant's intention.'

Secondly, the court of second instance also held that 'tort law cannot protect all rights and interests equally and these rights and interests should be ranked.' The court then explained that 'protecting human dignity and physical property is more important than protecting pure economic interests; pure economic interests should be protected, only if strict conditions can be satisfied.' According to the court, these conditions include: (1) whether the defendant acted intentionally or negligently;

34 See Chongqingshi qianjiangqu minzu yiyuan v Chongqingshi qianjiangqu yong'anjianzhu youxian zeren gongsi \& Chongqingshi qianjiangqu gongdian youxian zeren gongsi caichan sunhai peichang jiufen'an (Chongqing Minzu Hospital v Chongqing Yong'an Construction Co, Ltd et al) (26 December 2005) Chongqing No 4 Interim People's Court (Court of Second Instance).

35 The GPCL is the basic law on civil matters, but the 1996 Electric Power Law is a special law which regulates the activities of the electric power industry. Note that in China, a distinction is made between basic laws (jiben falü) and special laws (tebie falü). The former refers to the statutes that fundamentally affect the entire society whereas the latter refer to those statutes that only have an effect in a particular area. More information on the difference between basic and special laws in China is provided by TW Simon/C Feng/LP Nelson, China's Changing Legal System: Lawyers \& Judges on Civil \& Criminal law (2016) 13; and JF Chen, Chinese Law: Context and Transformation (2008) 242.

36 The 1996 Electric Power Law was enacted by the Standing Committee of the NPC and came into effect on 1 April 1996. 
(2) whether the plaintiff has obligations to tolerate the interference, taking the position of a neutral person; and (3) whether allowing the plaintiff's claim will impose an excessive financial burden on the defendant (the floodgate concern) ${ }^{37}$ In this cable case, the court decided that the plaintiff should not be allowed to recover its loss of profits, not only because 'the defendant caused the harm through negligence', but also because 'the duration of the power cut was short (which is tolerable)' and 'the fear that widespread liability would place an excessive financial burden upon the defendant, would be unfair and unjust, and impose burdens upon the entire economy.' Here, the main legal bases are arts 5, 106, and 117 of the GPCL. ${ }^{38}$

In addition to all these arguments, the court of second instance also pointed out that the plaintiff cannot claim compensation of its losses because its 'right to business' (ying ye quan) has been violated. ${ }^{39}$ According to the court, to violate this right, the defendant's act should be directed 'particularly against the plaintiff and directly affect the plaintiff's business activities'. In this cable case, however, the defendant's act affected not only the plaintiff but also other households and customers who live near the scene of the incident. Therefore, the court decided that the violation of the right to business cannot be invoked by the plaintiff to recover its loss of profits.

37 Though not always noticed, the court here mentioned only one strand of the floodgate argument. The other two strands are: (1) the fear that allowing recovery of pure economic loss would unleash a wave of actions that could overwhelm the courts; and (2) the belief that permitting the recovery of pure economic loss may encourage resistance to the trend toward expansion of liability. See VV Palmer/M Bussani, The Present Study, in: VV Palmer/M Bussani (eds), Pure Economic Loss: New Horizons in Comparative Law (2009) 25-27. See also an editorial by J Spier (ed)/C von Bar, The Limits of Expanding Liability: Eight Fundamental Cases in a Comparative Perspective (1998) for a more detailed discussion of the negative effects of expanding liability and the techniques used in different countries to limit such an expansion.

38 Art 5 of the GPCL states that: 'the lawful civil rights and interests of citizens and legal persons shall be protected by law; no organisation or individual may infringe upon them.' Art 106 of the GPCL requires that: 'citizens and legal persons who breach a contract or fail to fulfil other obligations shall bear civil liability.' Art 117 of the GPCL reads as follows: 'Anyone who damages the property of the State, a collective or another person shall restore the property to its original condition or reimburse its estimated price. If the victim suffers other great losses therefrom, the infringer shall compensate those losses as well.'

39 In Germany, the Supreme Court also created the 'right to business' to provide a better means of obtaining compensation for pure economic loss based on negligent conduct. A more detailed discussion of this right is provided by JM van Dunné, Liability for Pure Economic Loss: Rule or Exception - A Comparatist's View of the Civil Law - Common Law Split on Compensation of Non-Physical Damage in Tort Law (1999) 7 European Review of Private Law 397, 397-428; see also van Dam (fn 1) $88 \mathrm{f}$. 
Lastly, note that the court of first instance cited art 60 of the 1196 Electric Power Law as the legal basis for granting compensation for pure economic loss, whereas the court of second instance held that this article should not be applied because, pursuant to this article, 'the damage suffered by the victim' should be limited to 'personal injury and damage to physical property' (excluding pure economic loss from the category). Based on this interpretation, the court of second instance decided that art 60 of the 1996 Electric Power Law should not be applied, as the victim only suffered pure economic loss rather than personal injury or property loss.

\section{E Case Five: transferred loss cases}

The phrase 'transferred loss' refers to situations where $C$ causes damage to $B$ or B's property, but a special relationship between A and B (or the law itself) transfers a loss that would ordinarily be B's onto A. One common example of such loss is a personal injury case. In cases of personal injury or death, spouses and children are often granted certain forms of compensation for the loss of financial support (ie costs related to nursing and living expenses for dependents) and sometimes for non-pecuniary loss (ie pain and suffering), on the grounds of art 119 of the GPCL and the judicial interpretation issued by the SPC. ${ }^{40}$ Apparently, the losses suffered by the injured person's spouses and children are purely financial, as they have suffered no previous injuries.

Another common example of a transferred loss case is when an employee is injured by a third person (the injurer) and is unable to work for a certain period. Article 11 of the 2004 SPC Interpretation on How to Deal with Personal Injury Compensation Claims states that:

....where an employee suffers a personal injury when carrying out an employment activity, the employer shall bear the liability for compensation. If a third person outwith the employment relationship causes personal injury to the employee, the compensation claim should be made against either the third person or the employer. The employer may, after being held liable to pay compensation, claim compensation from the third person... The present Article shall not apply to labour relationships or work-related injury insurance, which should be governed by the Regulation on Work-Related Injury Insurance.

40 See art 119 of the GPCL. See also arts 17, 21, 22, 23, 27 and 28 of 2004 the Interpretation of the SPC on How to Deal with Personal Injury Compensation Claims. 
Apparently, according to this provision, the employer in China is allowed to recover from the injurer the compensation that it has paid to the injured employee if the employer has not joined the Work-Related Insurance (WII) Scheme. ${ }^{41}$ Note that if the employer is required to join the WII Scheme by law but fails to do so, it will not be allowed to recover the compensation. An illustrative example is a case where a worker, Mr Feng, was injured in a traffic accident that was caused by Mr Tang. ${ }^{42}$ The accident occurred in the course of Mr Feng's work, but Mr Feng's employer had not taken out WII cover for him (even though the law requires this to be done). As a result, the employer itself has to bear the medical expenses, nursing costs, and the loss of salary that were incurred by Mr Feng. After the payment of these amounts, Mr Feng's employer initiated a claim against the actual injurer, asking the injurer to reimburse the compensation that it had paid to its injured worker. The claim was denied by the court, because the court deemed that the losses suffered by the employer actually resulted from the failure to take out WII. Given this fact, the court decided that allowing the employer to claim compensation from the injurer goes against the aim of the WII scheme, as the employer is supposed to join the WII scheme. If the employer's claim were allowed, it would not have to bear the risk of being uninsured and would have no incentive to join the WII Scheme.

\section{A summary of the case study results}

What can we learn from the results contained in the judicial decisions? First, the case studies presented in section II show that even though almost all courts admit the recovery of intentionally caused pure economic loss, ${ }^{43}$ the legal basis that they used to arrive at these decisions is quite varied (see Table 1).

41 Note that, in China, if the employee's injury occurred in the course of work, their loss is often covered by the Work-Related Injury Insurance (WII). In China, the WII is solely funded by the employer at a rate of $0.5 \%, 1 \%$, or $2 \%$ of its payroll, depending on the health and safety risk of the employee's work. The coverage under WII is normally paid regardless of the insured's fault, but pain and suffering is excluded from the WII coverage. See art 38 of the 2011 Social Insurance Law. 42 Available at <http://hbqfy.chinacourt.org/public/detail.php?id=3677> (visited on 20 May 2019).

43 The court's reasoning in Case one ('unfair competition'), Case two ('flawed professional advice or services'), Case three ('interference with business'), and Case four ('cable cases') all reflect the idea that pure economic loss is recoverable if it is intentionally inflicted by the defendant. See above subsections II.A and II.B. 
Table 1: Legal Basis for the Recovery of Pure Economic Loss Used by Chinese Courts in Different Cases

\begin{tabular}{|c|c|c|}
\hline & Basis in Laws & Basis in SPC's Interpretation \\
\hline \multicolumn{3}{|c|}{ Case One ('unfair competition') - Arts 4,5 , and 7 of the GPCL } \\
\hline $\begin{array}{l}\text { Case Two ('flawed professional } \\
\text { advice or services') }\end{array}$ & $\begin{array}{l}\text { - Art } 106 \text { of the GPCL } \\
\text { - Art } 49 \text { of } 1996 \text { Lawyer's Law } \\
\text { - Arts } 42,54 \text { of } 1993 \text { Law on } \\
\text { Certificated Public Accountant } \\
\text { - Arts } 57 \text { and } 58 \text { of } 1993 \\
\text { Product Quality Law } \\
\text { - Art } 44 \text { of } 2006 \text { Agricultural } \\
\text { Product Quality Safety Law } \\
\text { - Art } 43 \text { of } 2006 \text { Notary Law } \\
\text { - Art } 207 \text { of } 2006 \text { Company } \\
\text { Law } \\
\text { - Art } 72 \text { of } 2016 \text { Seed Law } \\
\text { - Art } 21 \text { of1993 Interim } \\
\text { Provisions on the Management } \\
\text { of the Issuing and Trading of } \\
\text { Stocks }\end{array}$ & $\begin{array}{l}\text { - Art } 27 \text { of } 2003 \text { Some } \\
\text { Provisions of the SPC on } \\
\text { Trying Cases of Civil } \\
\text { Compensation Arising from } \\
\text { False Statements in Securities } \\
\text { Market } \\
\text { - } 1997 \text { Reply of the SPC on } \\
\text { How to Divide the Loss } \\
\text { Suffered by Multiple Creditors } \\
\text { Among Verification } \\
\text { Organizations } \\
\text { - } 1998 \text { Reply of the SPC on the } \\
\text { Liability of Accounting Firms If } \\
\text { They Issued False Capital } \\
\text { Verification Certificate to } \\
\text { Enterprises } \\
\text { - Arts } 2 \text { and } 4 \text { of } 2007 \text { Several } \\
\text { Provisions of the SPC on the } \\
\text { Trial of Compensation Cases } \\
\text { for Civil Tort Involving } \\
\text { Accounting Firms Engaging in } \\
\text { the Audit Business }\end{array}$ \\
\hline $\begin{array}{l}\text { Case Three ('interference with } \\
\text { business') }\end{array}$ & $\begin{array}{l}\text { - Arts } 5,106,117 \text { of the GPCL } \\
\text { - Art } 6 \text { of the TLL }\end{array}$ & \\
\hline Case Four ('cable case') & - Arts $5,106,117$ of the GPCL & \\
\hline Case Five ('transferred loss') & - Art 119 of the GPCL & $\begin{array}{l}\text { - Arts } 11,17,21-23,27,28 \text { of } \\
\text { the } 2004 \text { SPC Interpretation on } \\
\text { How to Deal with Personal } \\
\text { Injury Compensation Claims }\end{array}$ \\
\hline
\end{tabular}

As shown in the Table, arts 5 and 106 of the GPCL are often employed by courts as the main legal basis for awarding compensation in cases of intentionally caused pure economic loss. However, these two articles are relatively vague. The former provides the general basis for protecting legal rights and interests, while the latter is normally considered as the general rule for fault liability. Therefore, it seems that, in China, cases of intentionally inflicted pure economic loss are in practice normally resolved through the general rule of negligence. These articles also imply that pure economic loss is recoverable in China if a legally protected right or 
interest has been violated ${ }^{44}$ and if the violation is committed intentionally or with fault. ${ }^{45}$

Moreover, the court's reasoning in Case three ('interference with business') further implies that it may not be easy for the plaintiff to satisfy the burden of proof in cases of intentionally caused pure economic loss. To meet the standards of proof required by the court, the plaintiff has to show that his/her legally protected right or interest has been violated and that pure economic loss was foreseeable for the defendant. ${ }^{46}$ Therefore, it seems that, in China, intentionally inflicted pure economic loss is recoverable in cases where such a loss was foreseeable, the conduct in question is regarded as culpable, and a legally acknowledged right or interest has been violated.

When it comes to cases of negligently caused pure economic loss, courts in China, either explicitly or implicitly, seem to hold that such a loss is in principle not recoverable. However, there are two exceptions. In these exceptional circumstances, the recovery of pure economic loss is normally due to the presence of a specific statute (or the presence of an interpretation issued by the SPC) rather than to the general tort rules in the GPCL or in the TLL (see Table 1).

The first exception arises in cases where the plaintiff's loss is caused by certain types of gross negligence by professionals, such as lawyers, notaries, accountants, and professionals who undertake asset valuation and capital verification. ${ }^{47}$ As shown in Wang Baofu v Beijing Sanxin Law Firm and China Southern Airlines Travel \& Tourists Company $v$ Yulong Travel Agency et al, people who render professional advice or services will be responsible for the pure economic loss of third parties with whom they had no direct contractual tie, provided that they acted

44 The argument that legally acknowledged rights should be protected differently is well established in the Germanic legal tradition. For an overview of this tradition, see WV Gerven, Of Rights, Remedies and Procedures (2000) 37 Common Market Law Rev 501, 187 ff; and van Boom (fn 2) 7-10. 45 All European jurisdictions studied in Bussani/Palmer (fn 7) permit recovery when pure economic loss is inflicted intentionally. The reason is that in such situations, the conduct in question is culpable, immoral or contrary to public policy. Moreover, the recovery of intentionally inflicted pure economic loss is also allowed in other non-European legal systems, eg Japan, the United States, Israel, and South Africa. For full details of these legal systems, see the analysis of $Y$ Nomi, Japan, in: VV Palmer/M Bussani (eds), Pure Economic Loss: New Horizons in Comparative Law (2009) 71-87; D Gruning, The United States, in: VV Palmer/M Bussani (eds), Pure Economic Loss: New Horizons in Comparative Law (2009) 134-165; T Gidron/B Shnoor, Israel, in: VV Palmer/ M Bussani (eds), Pure Economic Loss: New Horizons in Comparative Law (2009) 186; and MM Loubser, South Africa, in: VV Palmer/M Bussani (eds), Pure Economic Loss: New Horizons in Comparative Law (2009) 218.

46 See above subsections II.B and II.C.

47 See Case two, which is discussed in subsection II.B. 
with gross negligence and that the third party reasonably relied on their professional services or advice. ${ }^{48}$ In fact, pure economic loss caused by experts or professional organisations is relatively well recognised in China. ${ }^{49}$ This seems to reflect the collective view that a high standard of professional services ought to be maintained on the market. ${ }^{50}$

Another exception is the 'transferred economic loss' case (Case five). ${ }^{51}$ Courts in China may compensate the injured person's family members for the reasonable value of care that they rendered to the injured person. The court may also protect the employer (via the recourse right) who is forced to continue paying an injured worker's salary without receiving any work in return. In both situations, the injured person's loss has been transferred, by statute or by contract, to their family members or employers. Even though the legislators do not specify why the recovery of transferred economic loss is allowed in China, the existing literature appears to suggest that the recovery might be justified for two reasons. One is that rejecting the recovery of 'transferred economic loss' that is suffered by the secondary victim will release the tortfeasor from liability, with the result that he/she benefits from his/her illegal behaviour..$^{52}$ Another reason is perhaps that cases

\section{Ibid.}

49 See arts 57 and 58 of the 1993 Product Quality Law; art 44 of the 2006 Agricultural Product Quality Safety Law; and art 72 of the 2016 Seed Law. These articles make it clear that any institutions or organisations which fabricate certificates or proof concerning the quality of a product (including the daily-used and agriculture product) that causes losses to the consumers shall be liable to pay compensation. See also art 54 of the 1996 Lawyer's Law; arts 2 and 4 of the 2007 Several Provisions of the SPC on the Trial of Compensation Cases for Civil Tort Involving Accounting Firms Engaging in the Audit Business; art 43 of the 2006 Notary Law; and art 207 of the 2006 Company Law. These articles clarify that for lawyers, accountants, notaries, and other professionals who undertake asset valuation, capital or other verifications, liability to pay compensation may be imposed if they acted with intent and gross negligence. More information on these articles can also be found at Zhang (fn 14) 468-472.

50 There is a consensus among many legal systems that a high standard of professional services could and ought to be maintained. Bussani and Palmer's comparative comments on the 'poor legal services case' (case 14), 'auditor's liability case' (case 17) and 'an anonymous telephone call case' (case 20) referred to this collective consensus. See M Bussani/VV Palmer, The Case Studies: National Reporters and Editors Commentary, in: M Bussani/VV Palmer (eds), Pure Economic Loss in Europe (Cambridge University Press 2003) 417, 471, and 519. However, among different legal systems, some may emphasise specific requirements in those cases (eg the third party is required to show its reliance on the professional services or advice), whereas others do not clearly impose such requirements.

51 See above subsection II.E.

52 See $C$ von Bar, The Common European Law of Torts (1998) 510f who argues that liability for transferred loss is aimed at preventing someone appealing to rules whose purpose is not to protect that person, but to protect others. 
involving such a loss are 'liability neutral' from the tortfeasor's perspective, as long as the full social cost of the accident is borne by the tortfeasor and there is no duplication of liability for the same loss. ${ }^{53}$

Lastly, the foregoing case analysis also shows that Chinese law lacks clear rules regarding pure economic loss in general (except in cases of 'flawed professional services' and 'transferred economic loss'). However, Chinese courts (often via the guiding case project) have developed certain techniques or requirements to determine the recovery of such loss in practice. For example, in Chongqing Min$z$ Hospital $v$ Chongqing Yong'an Construction Co, Ltd et al, the court explicitly referred to the floodgates argument as well as to the argument concerning the ranking of all rights and interests protected by tort law and the claimant's obligation to tolerate the interference when denying the recovery of pure economic loss. ${ }^{54}$ In Shanghai Lanqi Telecommunication Equipment Co, Ltd v Shanghai Yangpu Digital Market Management Co, Ltd (Case three), the court developed the foreseeability test and implicitly expressed the fear that allowing recovery would expose the defendant 'to a liability in an indeterminate amount for an indeterminate time to an indeterminate class' ${ }^{55}$

\section{Re-thinking the current Chinese approach}

At first glance, China appears to support awarding compensation for pure economic loss, as arts 5 and 106 of the GPCL, as well as art 6 of the TLL are very general and comprehensive. However, the foregoing analysis shows that the practice of the Chinese courts adopts a more intermediate or even a conservative position. Table 2 below summarises the results of the cases that were studied in the previous sections. ${ }^{56}$ The results are divided into two categories: a 'Yes' means that compensation for pure economic loss would be granted; a 'No' means that com-

53 See Bussani/Palmer (fn 2) 11f.

54 See Case four which is discussed in subsection II.D.

55 See Case three in subsection II.C. See also Yongkang Liangda Electronics Factory $v$ Yongang Ruiying Industry and Trade et al, which is discussed in subsection II.C. The 'indeterminacy' argument was originally proposed by an American judge, Cardozo, in the famous Ultramares case. In this case, the judge held that negligent accountants should not be liable to compensate damage suffered by third parties, because they would be exposed to a liability 'in an indeterminate amount for an indeterminate time to an indeterminate class'. See Ultramares Corp v Touche (1931) $255 \mathrm{New}$ York Reports (NY) 170, 174.

56 In the table, case numbers can be read as follows: Case 1 (unfair compensation case); Case 2 (flawed professional services or advice case); Case 3 (interference with business case); Case 4 (cable case); Case 5 (transferred loss case). 
pensation for such loss would be denied. Moreover, a distinction is also made between cases where the recovery can be attained in tort or by specific statute.

As shown in the Table, in cases where the loss is intentionally inflicted, compensation will always be awarded. However, certain requirements must be met, eg the defendant has to be culpable, the loss has to have been foreseeable, and protected rights or interests have been violated..$^{57}$ The rationale for recovery in such cases is straightforward. Denying recovery would create incentives for a tortfeasor acting with intent to cause a pure economic loss to the victim. Consequently, a third party, who would not have to face any tortious liability, could benefit from a rule of no recovery. ${ }^{58}$

Table 2: Results of the Pure Economic Loss Cases in China

\begin{tabular}{lll}
\hline & $\begin{array}{l}\text { Intentionally Caused Pure } \\
\text { Economic Loss Cases }\end{array}$ & $\begin{array}{l}\text { Negligently Caused Pure } \\
\text { Economic Loss Cases }\end{array}$ \\
\hline Yes (general tort rules) & $\begin{array}{l}1 ; 3 ; 4 ; 5 \\
\text { Yes (specific statute) }\end{array}$ & $\begin{array}{l}\text { 1(after 1993, when the 1003 } \\
\text { Unfair Competition Law was } \\
\text { enacted); } 2\end{array}$ \\
\hline No & 2 \\
\hline
\end{tabular}

Table 2 also shows that in cases where the loss was negligently caused, courts in China often proceed from an exclusionary position: the recovery of pure economic loss is in principle not allowed, except in defined and limited circumstances, such as the transferred loss and the flawed professional services cases. Moreover, for cases where the recovery of pure economic loss is denied, Chinese courts have developed several arguments, such as the threat of opening 'floodgates', the ranking of rights and interests, and the uncertainty/unforeseeability concern to support their decision. ${ }^{59}$ In the following subsections, the current Chinese approach as well as the arguments that are used to deny compensation for pure economic loss will be critically analysed.

57 See above section III.

58 See F Parisi/VV Palmer/M Bussani, The Comparative Law and Economics of Pure Economic Loss (2007) 27 International Rev of Law Economics 29, 46.

59 See above section III. 


\section{A Rationale of the arguments for denying recovery}

As mentioned before, in cases of negligently inflicted pure economic loss, Chinese courts often proceed from an exclusionary position and set out several arguments in support of denying compensation. ${ }^{60}$

The first line of argument is often grounded on the belief that allowing recovery would cause problems of open-ended liability and derivative litigation (often referred to as the floodgate problems). For instance, in Case four ('cable case'), the court of second instance clearly fears that permitting recovery would overwhelm courts and place an excessive financial burden upon the defendant. ${ }^{61}$ Some scholars argue that such fear makes sense, as derivative litigation would increase the administrative costs of the legal system, which ultimately increases the total social costs of accidents. ${ }^{62}$ However, from a scientific or a comparative point of view, the derivate litigation argument lacks justification. Empirically, there is a lack of solid evidence to prove that derivative litigation will actually follow in practice. If we take a look at the liberal regimes in Europe (eg France) where there is a broad recoverability of pure economic loss, it has to be admitted that these countries are not flooded with such claims. ${ }^{63}$ When it comes to the problem of open-ended liability, it should be stressed that not all pure economic loss cases pose an excessive burden on the tortfeasor's limited assets. ${ }^{64}$ For instance, in Case five ('transferred loss case'), the open-ended liability problem does not exist whereas in other relational pure economic loss cases (eg Case four, 'cable case'), the tortfeasor may face the real risk of unbearable financial consequences. ${ }^{65}$ Additionally, many instances of physical losses seem to cause even greater floodgate problems, but their compensation is not questioned. ${ }^{66}$ All these facts may, to a certain extent, help to explain why liberal regimes in Europe are not flooded with pure economic loss claims. Just as some studies have argued, although these regimes generously allow such claims in practice, the extent of liability is largely limited by implementing various legal instruments, eg require-

60 See above subsections II.B, II.C, and II.D.

61 See above subsection II.D.

62 See Palmer/Bussani (fn 37) 31.

63 See J Spier/O Haazen, Preliminary Observations, in: J Spier (ed), The Limits of Expanding Liability: Eight Fundamental Cases in a Comparative Perspective (1998) 7.

64 See Fleming James, Limitations on Liability for Economic Loss Caused by Negligence: A Pragmatic Appraisal (1972) 12 Journal of the Society of Public Teachers of Law (New Series) 105, 115.

65 See above subsection II.D.

66 See M Bussani/VV Palmer/F Parisi, Liability for Pure Financial Loss in Europe: An Economic Restatement (2003) 51 AJCL 113, 113-162 for a critical discussion of the floodgate arguments. 
ments concerning causation, proof of damage, and the duty of the victim to mitigate damage. ${ }^{67}$

The ranking of legal rights and interests argument is a second line of argument that is often used by Chinese courts to deny the recovery of pure economic loss (eg in Case four). According to this argument, there is a necessity to weigh human values against legal rights, and pure economic interests are said to occupy levels below bodily integrity and property. ${ }^{68}$ Such argument seems to rest upon a premise that compensation is a scarce commodity and the law cannot simultaneously protect all values fully. ${ }^{69}$ This premise is not very convincing. ${ }^{70}$ On the one hand, in some cases, the consequences of cases of pure economic loss can be very devastating, just as the consequences of personal injury and death cases. On the other hand, there is no empirical support for the assumption that the limits of compensation have ever been reached. ${ }^{71}$ Therefore, it seems that the ranking of legal rights and interests argument cannot be, or at least cannot be the only reason for fully barring recovery of pure economic loss. ${ }^{72}$ For example, this argument cannot explain why intentionally inflicted pure economic loss and consequential economic loss are recoverable in most jurisdictions. ${ }^{73}$ In fact, the denial of com-

67 See Spier/Haazen (fn 63) 12. See also M Barendrecht, Pure Economic Loss in the Netherlands, in: E Hondius (ed), Netherlands Reports to the Fifteenth International Congress of Comparative Law (1998) 126. For example, the courts in the Netherlands are allowed to reduce the amount in damages whenever full compensation would lead to clearly unacceptable results such as bankruptcy of the debtor. See art 6:109 BW. On the compensation of pure economic loss in the Netherlands, see Bussani/Palmer (fn 3) 139-147.

68 The fact that there is a deep-seated preference for the protection of property interests over and above pure economic interests in tort law is well recognised in the literature. However, the existing justifications of such a preference are found to be either ad hoc in nature or of limited explanatory power. See $C$ Witting, Distinguishing between Property Damage and Pure Economic Loss in Negligence: A Personality Thesis (2001) 21 Legal Studies (LS) 481, 481-514 for a detailed examination of the justifications for the ranking of legal rights and interests argument.

69 See van Boom (fn 2) 46-48.

70 One possible justification for the ranking of legal rights and interests argument may rest on the basis of Hegel's 'personality thesis'. This means that 'although wealth permits the acquisition of property and participation in activities and experiences which may help to constitute and define the self in the future, the mere fact that wealth has not been transposed into these things excludes it from being considered as important as actual holdings of property.' See Witting (2001) 21 LS 481, 505-513.

71 Ibid.

72 Just as van Boom (fn 2) 44-46 suggested, a modern civil code or modern tort law should respond to the development of intangible wealth and the growing public awareness of protecting purely economic interests. Therefore, the more modern view of tort law would not be to fundamentally treat life, health, and property differently from pure economic interests.

73 See J De Mot, Pure Economic Loss, in: M Faure (ed), Tort Law and Economics (2009) 203. 
pensation for pure economic loss is often interrelated with many other factors, such as the extent to which the damage could be foreseen, or the tortfeasor blamed, or the size of the plaintiff class, or the public policy toward professional standards could be assessed, and so forth. Therefore, it seems that when addressing the recoverability of pure economic loss, an appropriate approach for policymakers is to carefully consider all these factors rather than simply the ranking of legal rights and interests. ${ }^{74}$

A third set of arguments refers to the concern that permitting the recovery of pure economic loss will cause ‘indeterminacy' concerns, as such cases involve an unknown number of potential victims, an uncertain amount of loss, and cases which are unforeseeable in nature. ${ }^{75}$ This argument is partially correct if we consider the fact that tort cases often involve strangers and that these parties cannot have the opportunity (as they do in contract cases) to ex ante assess the number, the nature, and the extent of possible pure economic claims. However, this argument neglects the fact that in certain pure economic loss cases, the indeterminacy problem does not exist. For example, in cases of 'unfair competition' (Case one) and 'transferred loss' (Case five), the number of potential victims as well as the likelihood of the damage are ex ante calculable. Moreover, it is still debated whether there is a wider range of victims and a wider extent of claims in pure economic loss cases than in cases of personal injury and property damage. Given all these facts, it can be concluded that the 'indeterminacy' argument holds only for certain types of pure economic loss cases (eg the 'cable case'). The application of this argument seems therefore to depend on the nature of the loss.

\section{B A view from law and economics}

As shown in the above section, arguments seeking to justify the denial of pure economic loss in China are largely debated and may even lead to practical inconsistencies. ${ }^{76}$ Due to this fact, in this subsection we turn to the law and economics

74 See van Boom (fn 2) 46-48. For example, cases studies in section 2 show that courts in China may reject the claim for pure economic loss, based on the uncertainty or unforeseeability of the loss. See above subsections II.C and II.D.

75 See van Boom (fn 2) 44-46.

76 See Bussani/Palmer/Parisi (2003) 51 AJCL 113, 113-162; G Dari-Mattiacci/HB Schäfer, The Core of Pure Economic Loss (2007) 27, International Review of Law and Economics (Int'l Rev L \& Econ) 8, 8-28; and Parisi/Palmer/Bussani, 27 Int'l Rev L \& Econ 29 all argue that traditional explanations (eg the floodgates argument, the scale of human values argument, and the need to reduce litigation costs argument) seeking to justify the non-recovery of pure economic loss often lead to practical inconsistencies. 
analysis and explain how such analysis could act as a tool to guide the recoverability of pure economic loss in China.

In the law and economic literature, the starting point is that compensation should be based on the social loss to provide the tortfeasor with optimal incentives to prevent the loss. ${ }^{77}$ In cases of pure economic loss, however, the private loss of the victim might be offset by private gains elsewhere. ${ }^{78}$ As a result, pure economic loss is more likely to involve a wealth transfer rather than to cause social loss. Since some pure economic loss cases involve no social loss, some economists argue that such loss should not be compensated. ${ }^{79}$ However, this assertion is challenged by other studies. The reasons are summarised as follows.

First, some pure economic loss cases do result in a social loss. For example, the cable case (Case four) often entails the impairment of resources and the increased capacity of the third party, both of which can be regarded as social losses. ${ }^{80}$ Moreover, in the flawed professional service case (Case two), there might also be a social loss, since trust in the information provided by the expert decreases and money is sub-optimally invested on the basis of incorrect information. ${ }^{81}$ Therefore, pure economic loss cases that entail those social losses should be compensated, otherwise the increased capacity of the third party will be inflated to an inefficiently high level. ${ }^{82}$ Consequently, the victim should in principle be compensated in the negligently caused cable case (Case four), even if no absolute rights are infringed. This is because in such cases, the market price of the

77 See J Arlen, Tort Damages, in: B Bouckaert/GD Geest (eds), Encyclopedia of Law and Economics (1999) 684.

78 See $W$ Bishop, Economic Loss in Tort (1982) 2 OJLS 1, 12.

79 The argument was first proposed by Bishop (1982) 2 OJLS 1, 1-29; and then developed by many subsequent works. See eg S Shavell, Economic Analysis of Accident Law (1987) 135ff; WM Landes/ RA Posner, The Economic Structure of Tort Law (1987) 251ff; F Gómez/JA Ruiz, The Plural-and Misleading: Notion of Economic Loss in Tort: A Law and Economics Perspective (2004) 12Zeitschrift für Europäisches Privatrecht (ZEuP) 908, 908-1031; and HB Schäfer/C Ott/M Braham, The Economic Analysis of Civil Law (2005) 301.

80 The impairment of resources involves social loss, as valuable resources cannot be used for a limited period of time, decreasing the utility that individuals derive from the recourses' uses. The wealth transfer from the tortfeasor to the third party comes at the cost of increased capacity. This increased capacity of the third party can be considered as a precaution cost, as the third party is provided with a valuable way to mitigate the total loss and such mitigation effort has a cost. See Dari-Mattiacci/Schäfer (2007) 27 Int'l Rev L \& Econ 8, 15-17.

81 See L Visscher, Tort Damages, in: M Faure (ed), Tort Law and Economics (2009) 169.

82 Moreover, Dari-Mattiacci/Schäfer (2007) 27 Int'l Rev L \& Econ 8, 17 further argue that if a third party has mitigated the accident loss, the compensation should equal the mitigation cost (eg the cost of repair, the cost of finding substitute goods or service) instead of the initial loss (the total reduction in the value of the goods or the service impaired). 
damaged cable cannot be assumed to capture the full surplus that the third parties obtain from its use. ${ }^{83}$ Hence, if liability is limited to the losses of the hospital, compensation would be lower than the social losses of the accident, causing the tortfeasor to take less than an optimal level of care.

Second, the wealth transfer argument presented above is grounded on an unrealistic assumption that substitute goods or services are readily available on the market at no cost. ${ }^{84}$ In reality, however, third parties will make gains only if they have excessive capacity to increase their production or provision of services. Such over-capacity might be inefficient in the first place, because if it is not utilised, the resources remain idle. ${ }^{85}$ Moreover, not compensating pure economic loss may also result in more over-capacity being needed, as there will be less liability and more accidents. ${ }^{86}$

Third, pure economic loss should even be compensated in some cases where it does not correspond to any social loss, on the condition that the third parties are willing to pay (or have actually paid) for protection against an involuntary wealth transfer. ${ }^{87}$ For example, in the flawed professional service or advice case (Case two), a lawyer or a notary is usually hired by the victim. The services or advice provided by these professionals usually exclusively benefit the victim or a limited group of third parties (eg the victim's heir or other intended beneficiaries). Since the price of services incorporates the expected liability of the expert, the victim is paying ex ante the price for an implicit warranty of the quality of the professional service. Therefore, even if the victimised parties have no contractual relationship with the expert, the liability risk of the expert remains the same and compensation for these parties' pure economic loss should still be paid. By contrast, in cases where the victim's private loss is higher than the social loss and the liability costs are not internalised in the price (because the victim is not willing to pay or for other reasons), compensation for pure economic loss should be restricted or denied. ${ }^{88}$ Otherwise, there will be a free-rider problem on the part of the victim. For example, in a flawed professional service case (Case two), we assume that an accountant or an auditor is hired by a client. Due to the nature of the services provided, the information provided by the accountant or the auditor may benefit

83 See De Mot (fn 73) 209.

84 See MJ Rizzo, The Economic Loss Problem: A Comment on Bishop (1982) 2 OJLS 197, $198 \mathrm{f}$.

85 See ibid; see also Bishop (1982) 2 OJLS 1, 5. Even though both articles agree that in cases of pure economic loss there is some unused capacity, their opinions diverge on whether this capacity is inefficient.

86 See Rizzo (1982) 2 OJLS 197, 202 and Visscher (fn 81) 168.

87 See Dari-Mattiacci/Schäfer (2007) 27 Int'l Rev L \& Econ 8, 18-20; see also De Mot (fn 73) 210f.

88 See Dari-Mattiacci/Schäfer (2007) 27 Int'l Rev L \& Econ 8, 20-22; see also De Mot (fn 73) 210f. 
more individuals (eg third party investors and financial institutions). If third parties other than the client (or his/her intended beneficiaries) can rely on the information and claim compensation without contributing to the cost of the service, the client would pay for the larger potential cost of liability. In turn, this would lead to a sub-optimal demand for professional services and an excessive expansion of the tortfeasor's exposure to liability.

From an economic point of view, it seems to be unconvincing to determine the compensation of pure economic loss solely on the basis of social loss. This is perhaps the reason why some economists are beginning to argue that the problem of pure economic loss actually originates from the fact that tort law is used to accomplish duplicate tasks, the internalisation of both negative and positive externalities. ${ }^{89}$ In an ideal word where both negative liability and positive liability could be used (a framework of decoupled liability), ${ }^{90}$ those who have suffered injury should be incentivised to act optimally, while victims and third parties should be incentivised to maintain optimal over-capacity. However, such a decoupling system is rarely implemented in reality, and legal systems normally rely on different forms of the negligence rule to determine the recovery of pure economic loss. From this premise, it is argued that to determine the recoverability of such loss, one has to take into account not only the magnitude of the damages award (eg whether compensation should include the victim's private loss or should be limited to the socially relevant loss), but also other elements of the legal system (eg the scope of the negligence rule, the implementation of subsidies and other incentive devices). ${ }^{91}$

\section{Conclusions and directions for the future}

In this article, we have re-examined the way in which Chinese legislators and courts have developed to cope with cases of pure economic loss. We have shown that the legal basis used to determine the recovery of pure economic loss in China is often unclear, and that the courts have developed a relatively conservative attitude towards the compensation of such loss in practice. ${ }^{92}$ Moreover, our analyses

89 See $G$ Dari-Mattiacci, The Economics of Pure Economic Loss and the Internalisation of Multiple Externalities, in: W van Boom/H Koziol/C Witting (eds), Pure Economic Loss (2004) 175ff.

90 This means that the injurer is liable for the pure economic loss but is compensated for the benefits of third parties; the victim is not compensated for pure economic loss but is compensated for benefits of third parties, and the third parties are allowed to keep their benefits. Ibid, 176.

91 Ibid, 188.

92 See above section III. 
have also showed that the arguments (eg floodgate, ranking of legal rights and interests, and indeterminacy arguments) adopted by Chinese courts to deny recovery are neither fair nor reasonable..$^{93}$ They normally lack scientific or comparative support and can only be used to deny compensation in a limited type of cases. Due to these problems, this article further turned to the law and economics literature to seek complementary solutions. ${ }^{94}$ According to such analyses, the tortfeasor should not be excluded from the duty to compensate merely on the basis of the nature of the damage he/she caused, but on the social loss generated. ${ }^{95}$ Fully excluding the recovery of pure economic loss not only leaves the victim with less than full compensation but also reduces the tortfeasor's incentives to avoid damage. ${ }^{96}$ Following this line of analysis, we suggest that socially relevant losses in cases of pure economic loss should be compensated. Since both the impairment of resources and the increased capacities used to substitute impaired resources can be regarded as a social cost, these losses should also be taken into account when calculating the amount of pure economic loss. In addition, in cases where pure economic loss does not correspond to a social loss, such a loss should also be compensated if third parties are willing to pay or have paid for protection against such loss.

Nonetheless, this does not mean that the authors advocate a broader scope of recovery of pure economic loss. What we really suggest is that the recoverability of pure economic loss is a complex issue and should never be resolved with a simple solution. ${ }^{97}$ As a matter of fact, legislators and courts in China should take note of the fact that pure economic loss often arises at the end of a long chain of events. Thus, certain legal concepts, such as causation and the duty of the victim to mitigate damage, need to be further clarified and more carefully designed in the future to cut this chain at some point..$^{98}$ Furthermore, when determining the extent of pure economic loss, the legislators or courts in China should cautiously

93 See above subsection IV.A.

94 See above subsection IV.B.

95 See van Boom (fn 2) 48.

96 See above subsection IV.B.

97 In this view, some of the suggestions that scholars have made seem to be simplistic and may only be applicable in the common law systems. For example, Barker ([2006] 26 OJLS 289, 289-302) argues that the House of Lords should endorse a single reasoning strategy to pure economic loss cases based on the three-stage approach in the Caparo case. $P$ Giliker, Revisiting pure economic loss: lessons to be learnt from the Supreme Court of Canada? (2005) 25 LS 49, 49-71 proposes that courts in the UK should adopt the 'categorization approach', developed by Canadian courts, towards pure economic loss claims.

98 Van Boom (fn 2) 48-52 and Dari-Mattiacci/Schäfer (2007) 27 Int'l Rev L \& Econ 8, 25 f also suggest the causation requirement could act as a 'safety valve' to relieve the excessive pressure im- 
balance a variety of factors, including but not limited to, the extent to which the damage could have been foreseen, the nature of the loss, the extent to which the tortfeasor is culpable, the size of the plaintiff class, the public policy toward professional standards, the victim's private loss, the social loss, the courts' capacities to calculate the loss, ${ }^{99}$ and the willingness of third parties to pay for protection against the loss. Therefore, the final decisions on whether the recovery of pure economic loss should be allowed in a particular case ought to be based upon a balanced approach, taking into account a trade-off between all these factors.

posed by the compensation for pure economic loss. The latter study further adds that the neverending chain is not a problem of pure economic loss alone; it is a more general problem.

99 Van Boom (fn 2) 48-52 suggests that the court should be endowed with the power to reduce compensation for pure economic loss when full compensation would certainly lead to unacceptable results. Dari-Mattiacci/Schäfer (2007) 27 Int'l Rev L \& Econ 8, 25 f however, mention that many legal systems exclude sentimental value or non-physical pain from compensation, as their calculation may overly burden the abilities and capacities of courts. 